\title{
PENINGKATAN TATA KELOLA PASAR SRI BANTAS DESA CEPAKA
}

\author{
Komang Fridagustina Adnantara ${ }^{1 *}$, Ni Luh Sili Antari ${ }^{2}$, \\ (Universitas Triatma Mulya ${ }^{\mathbf{1 , 2}}$ ) \\ frida.adnantara@triatmamulya.ac.id ${ }^{*}$
}

\begin{abstract}
Sri Bantas Traditional Market is one of the traditional markets located on Jl. Raya Munggu Br. Batanduren, Cepaka Village, Kediri District, Tabanan Regency. The objective in implementing this service is to provide assistance in the governance of the Sri Bantar Village market in Cepaka. The problems identified include: some traders in the Sri Bantas market have not implemented financial accounting practices, the lack of infrastructure arrangement in the Sri Bantas market, and the lack of a promotional strategy for traditional markets in the Sri Bantas market. The methods used in this assistance were interviews, observation, and data analysis. The work programs carried out in the Sri Bantas market were: 1) providing information about simple bookkeeping to market traders, 2) procuring hand washing stations, 3) procuring market block names ,4) data collection of traders, 5) making banners, and 6) making online pamphlets. The result of this activity is that some traders know the importance of making financial reports and how to make simple financial reports, up to date trader data has been inputted into the market system, the market is better known by the wider community.
\end{abstract}

Keywords: governance, sri bantas traditional market.

\section{PENDAHULUAN}

Selingsing Cepaka demikianlah sapaan akrab dalam keseharian kami sebagai warga desa yang masih menjaga keasrian dan tradisi budaya yang telah ada. Desa Cepaka terletak di bagian paling timur Kecamatan Kediri, Kabupaten Tabanan-Bali. Sebuah desa yang berbatasan dengan Kabupaten Badung ini masih alami dengan lestarinya lahan persawahan membentang mengelilingi Desa Selingsing ini. Pertumbuhan perekonomian masyarakat Desa Cepaka menggeliat secara signifikan sejak dibangun pasar tradisional milik masyarakat Desa Cepaka yang bernama pasar "Sri Bantas".

Pasar Tradisional Sri Bantas adalah salah satu pasar tradisional yang terletak di Jl. Raya Munggu Br.
Batanduren, Desa Cepaka, Kecamatan Kediri, Kabupaten Tabanan. Letak Pasar Sri Bantas yang strategis yaitu terletak di pinggir jalan utama dan disekitar perumahan yang ada di Desa Cepaka juga menjadi nilai plus untuk menambah keuntungan bagi pasar itu sendiri. Pasar ini dibangun pada tahun 2011 yang digagas oleh Bapak Drs, I Ketut Tedja, Msi., yang pada saat itu beliau masih bertugas disalah satu perusahaan BUMN daerah Bali. Ide awal mendirikan pasar tradisional Sri Bantas ini adalah dengan memanfaatkan lahan sawah seluas 60 are atau 6.000 meter persegi yang yang lahan sawah tersebut dulunya kurang produktif menghasilkan, maka timbul gagasan dari Drs. I Ketut Tedja, Msi., bersama rekan beliau yaitu 
Bapak I Nyoman Susila, ST., MM. Sebagai penyedia sumber dana pembangunan pasar, maka dialih fungsikanlah lahan tersebut menjadi sebuah pasar tradisional yang dapat membuka peluang minat dan daya tarik warga banjar desa setempat untuk menjadi wirausahawan berdagang di Pasar Sri Bantas.

Menurut pimpinan Kepala Pasar Sri Bantas Bapak Nyoman Mega Nopiudya, SE., saat ini pasar ini menyediakan los dagang sebanyak 230 dan kios sebanyak 44 unit. Los dan kios tersebut disewakan dengan Hak Guna Pakai (HGP) masing masing selama 25 tahun dengan harga $\mathrm{Rp}$ 15.000.000 per los dan Rp 25.000.000 per kios, selama kepemilikan hak guna pakai baik los maupun kios juga dapat dikontrakan kepada pihak ketiga dengan status kontrak atas dasar perjanjian dan kesepakatan dari pemilik los/kios dengan pengontrak dengan harga sesuai kesepakatan kedua belah pihak.

Dengan luas area yang cukup luas yaitu 60 are, Pasar Sri Bantas tertata dengan rapi, mulai dari area parkir untuk pembeli dibagian depan, kios-kios dibangun pada sisi kanan dan kiri, sedangkan los-los berada pada bagian tengah dan parkir untuk para pedagang berada diarea paling belakang pasar. Pasar Sri Bantas saat ini buka dari pagi jam 06:00 - 11:00, dimana tersedia berbagai jenis kebutuhan seperti pedagang kelontongan, pakaian, kue, canang dan sarana upacara, sembako, buah, sayur, ikan dan daging. Selain itu dipasar Sri Bantas juga terdapat pedagang berbagai macam bunga hias, ikan hias dan makanan dan minuman es cendol dawet dan bubur kacang ijo. Meski jam buka pasar ini hanya dipagi hari namun ada beberapa pedagang yang masih buka sampai sore hari karena terdapat pelanggan yang belanja sampai sore hari.

Menurut kepala pasar Sri Bantas Bp. I Nyoman Mega Nopiudya, SE. kedepannya telah direncanakan membuka pasar senggol dimalam harinya mulai pukul 16:00 - 22:00 malam. Hal ini tentu akan lebih memberikan peluang lapangan kerja bagi masyarakat setempat maupun bagi masyarakat umum yang ingin berusaha sebagai pedagang sehingga memberikan dampak pada pertumbuhan perekonomian bagi masyarakat sekitar.Berdasarkan hasil observasi dan dialog dengan kepala pasar dan pedagang di pasar tradisional Sri Bantas terdapat beberapa permasalahan yang ada di Pasar Sri Bantasantara lain: 1) Beberapa pedagang-pedagang di Pasar Sri Bantas belum melaksanakan praktek akuntansi keuangan. Kebanyakan pedagang di Pasar Tradisional Sri Bantas menggunakan bentuk pencatatan yang tidak tertulis. Bentuk pencatatan yang tidak tertulis merupakan bentuk akutansi yang tidak terlihat wujudnya, hanya ada dipikiran saja. Pencatatan tertulis dianggap cukup merepotkan untuk dipraktikkan oleh pedagang sehingga tidak secara spesifik melakukan; 2) Kurangnya penataan infrastruktur di pasar Sri Bantas. Tata letak pedagang yang belum teratur dalam segi pengelompokan dagangan yang dijual. Belum adanya blok-blok petunjuk yang memudahkan pembeli yang datang ke pasar Sri Bantas tidak binggung saat berbelanja. Dan dari segi protokol kesehatan di Pasar Tradisonal Sri Bantas hanya ada 1 set tempat cuci tangan; 3) Kurangnya strategi promosi untuk pasar tradisional di pasar Sri Bantas. Masih 
banyak yang belum mengetahui adanya pasar tradisional Sri Bantas dan masih ada beberapa slot kosong bagi pedagang yang ingin berjualan.

\section{METODE PELAKSANAAN}

Pelaksanaan pendampinganini dilakukan dengan tiga tahapan, dimana tahap pertama merupakan tahap persiapan. Pada tahap ini dilakukan survey pendahuluan untuk melihat kondisi pasar Sri Bantas yang terletak di Jl. Raya Munggu Br. Batanduren, Desa Cepaka, Kecamatan Kediri, Kabupaten Tabanan. Dalam tahap ini di identifikasi permasalahanpermasalahan yang di hadapi oleh pedagang dan juga pengelola pasar Sri Bantas. Tahap selanjutnya merupakan tahapan pelaksanaan kegiatan pengabdian. Dalam tahap ini dilakukan kegiatan yang sudah direncanakan yaitu pengelolaan laporan keuangan pada pedagang pasar, penataan insfrastuktur dan kegiatan stategi promosi pasar. Tahap yang terakhir adalah tahap evaluasi. Pada tahap ini dilakukan evaluasi atas hasil yang telah dicapai, masukan dan perbaikan lebih lanjut dapat dilakukan pada tahap ini.

\section{HASIL DAN PEMBAHASAN}

Pelaksanaan

kegiatan

pendampingan di Pasar Sri Bantas sudah dijalankan sesuai rencana dan mampu mencapai tujuan yang diinginkan. Pada program kelompok terdapat 3 program kerja yang dilaksanakan yaitu pengaplikasian laporan keuangan sederhana kepada para pedagang di Pasar Sri Bantas, penataan infrastruktur pasar dan pemasaran pasar. Hasil pelaksanaan dari program kerja berlangsung efektif. Sosialisasi terkait pengaplikasian laporan keuangan yang sederhana telah dilakukan ke beberapa pedagang mengingat betapa pentingnya laporan keuangan sebagai catatan atas transaksi yang dilakukan dan mengajarkan kepada para pedagang pelaporan pencatatan yang sederhana dan mudah dimengerti. Selanjutnya penataan infrastruktur pasar meliputi update data pedagang, pembuatan nama blok pasar, dan pemasangan tempat cuci tangan telah direalisasi dengan baik sehingga fasilitas dan lingkungan pasar menjadi lebih nyaman. Terakhir, pada program kerja pemasaran pasar, dilakukan strategi promosi berupa penyebaran pamflet secara online di sosial media dan pembuatan banner yang dipasang di Pasar Sri Bantas telah terlaksana dengan lancar. Meskipun terdapat hambatan atau kendala pada pelaksanaan program namun masih bisa diatasi.

\section{KESIMPULAN}

Beberapa hasil yang telah dicapai pada kegiatan pendampingan ini diantaraya adalah memberikan pemahaman dan penyuluhan tentang pentingnya laporan keuangan, serta mengajari pembuatan laporan keuangan sederhana yang dapat langsung di praktekan di lapangan. Melakukan penataan beberapa infrastruktur serta menambahkan beberapa infrastruktur sesuai proker seperti pengadaan tempat cuci tangan dan pemasangan blok pasar yang memudahkan para pengunjung pasar dan pedagang. Melakukan promosi pasar melalui media social seperti Facebook dan Instagram untuk memperkenalkan pasar terhadap masyarakat luas. Adapun saran yang dapat diberikan adalah:

1. Melalui pendapingan tata kelola Pasar Sri Bantas diharapkanuntuk 
lebih memperhatikan berbagai unsur pendukung terhadap pasar dan pedagang Pasar Sri Bantas itu sendiri. Dengan demikian pengelola pasar tidak hanya bertugas untuk menarik retribusi semata namun juga memberikan bentuk-bentuk dukungan kepada Pedagang Pasar Sri Bantas dan pengelola pasar.

2. Memperbaiki internal pasar seperti; ketertiban, kenyamanan, kebersihan. Karena kemungkinan besar konsumen enggan berbelanja ke pasar tradisonal dikarenakan kondiri pasar yang tidak nyaman.

\section{UCAPAN TERIMA KASIH}

Ucapan terimakasih penulis berikan kepada:

1. DR. I Ketut Putra Suarthana, MM., Rektor Universitas Triatma Mulya.

2. DR. I Nengah Aristana, SE.,MM., Selaku Dekan Universitas Triatma Mulya.

3. A.A. Ketut Sri Asih., SE., Selaku Koordinator Program Studi Manajemen.

4. I Ketut Tedja., M.Si., Selaku Kepala Desa Adat Cepaka, Kecamatan Kediri, Kabupaten Tabanan.

5. Nyoman Mega Nopiudya., SE., Selaku Kepala Pasar Tradisional Sri Bantas.

6. Segenap pihak yang telah membantu dalam memudahkan kelancaran kegiatan survey $\mathrm{KKN}$ Kelompok VIII Tahun 2020 hingga penyusunan Laporan Pelaksanaan Kegiatan KKN ini.

\section{DAFTAR PUSTAKA}

Data Pengelolaan Pasar Dan Struktur Organisasi Pasar Tradisional Sri Bantas. (2020). 